\title{
Effect of Different Operating Conditions on the Corrosion of Carbon Steel in Oxygenated Sodium Sulphate Solution
}

\author{
Sara A. Sadek \& Basim O. Hasan \\ Chemical Engineering Department, Al-Nahrain University, Iraq
}

\section{Abstract :}

Carbon steel is a major metal used in manufacturing of the equipments used in petroleum industry and it is subject to different operating conditions causing various corrosion attacks. Corrosion of carbon steel in sodium sulphate solution $\left(\mathrm{Na}_{2} \mathrm{SO}_{4}\right)$ under flow conditions was investigated using rotating cylinder electrode (RCE) for a range of rotation velocity $(0-2000 \mathrm{rpm})$ and temperatures $\left(32-52{ }^{\circ} \mathrm{C}\right)$. The corrosion rate was determined by using both weight loss method and electrochemical polarization technique (limiting current density). Different salt concentrations were investigated ranged from 0.01 to 0.4 M. The effect of time (or corrosion product formation) and the effect of oxygen concentration through air bubbling in the solution were also investigated and discussed. The results showed that increasing rotational velocity leads to a considerable increase in the corrosion rate represented by limiting current density. The corrosion rate had unstable trend with salt concentrations and temperature. Generally, the corrosion rate decreased appreciably with time due to the formation of corrosion product layer depending on rotational velocity, temperature, and oxygen concentration. It was found that, air pumping through the salt solution leads to a considerable increase in the limiting current density $\left(\mathrm{i}_{\mathrm{L}}\right)$ depending on rotational velocity, temperature, and time.

Keywords: corrosion, carbon steel, sodium sulphate, velocity, oxygen. 


\section{Introduction}

In petroleum industry the equipments are subject to corrosive environments causing different operational problems. Studying the corrosion behavior of carbon steel under different operating conditions is of vital importance of petroleum industry. Salts dissolved in water have a marked influence on the corrosivity of water. At extremely low concentrations of dissolved salts, different anions and cations show varying degrees of influence on the corrosivity of the water. The anions most commonly found in water are chloride, sulphate and bicarbonate. There are many investigations for corrosion of carbon steel in neutral aerated salt solutions, especially in sodium chloride $(\mathrm{NaCl})$ solution. Little investigation has been found for corrosion of carbon steel in $\mathrm{Na}_{2} \mathrm{SO}_{4}$ salt solution. The sulphate ion has a greater effect on the corrosivity of the water than the chloride ion, and the bicarbonate ion shows inhibitive tendencies. In addition sodium sulphate is presented in considerable concentration in the accompanying water with crude oil causing corrosion for the handing pipelines. Generally corrosion of turbine caused by a thin film deposit of fused salt (sodium sulphate) on alloy surface (carbon steel) is an example of corrosion in sodium sulphate $[1,2]$. During combustion in the gas turbine, sulfur from the fuel reacts with sodium chloride from ingested air at elevated temperatures to form sodium sulphate. The sodium sulphate then deposits on the hot-section components, such as nozzle guide vanes and rotary blades, resulting in accelerated oxidation attack [3]. Sodium sulphate also cusses corrosion in boiler that used sodium sulfite $\left(\mathrm{Na}_{2} \mathrm{SO}_{3}\right)$ as oxygen scavenger when $\mathrm{Na}_{2} \mathrm{SO}_{3}$ reacted with oxygen at low temperature and pressure it forms sodium sulphate that causes serious attack to the tubes of the boiler [4]. Despite its relatively limited corrosion resistance, carbon steel is used in large tonnages in marine applications, nuclear power and fossil fuel power plants, transportation, chemical processing, petroleum production and refining, 
pipelines, mining, construction and metal-processing equipment [5]. The following reactions occur as the result of the corrosion of carbon steel in sodium sulphate $\left(\mathrm{Na}_{2} \mathrm{SO}_{4}\right)$ aqueous solutions [6]:

$\mathrm{Fe}_{(\mathrm{s})} \leftrightarrow \mathrm{Fe}^{+2}+2 \mathrm{e}^{-}$

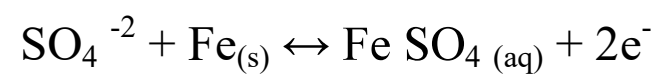

It is well known that the rate controlling step in most natural water corrosion process is the cathodic half reaction. The most important cathodic process in aerated waters is oxygen reduction. The rate of this half reaction is generally limited by the speed at which oxygen can reach the surface of the metal. This oxygen is transported from the bulk water to the surface across the boundary layer by diffusion. The oxygen concentration will vary from a minimum at the surface to bulk concentration at the outside edge of the boundary layer. This results in the concentration gradient and promotes the transport of oxygen [7]. If the corrosion process is under cathodic diffusion control then the flow increases the corrosion rate. This effect generally occurs when an oxidizer is present in small amounts, as is the case for dissolved oxygen in acids or water [8]. The effects of concentration, velocity, and temperature are complex and it will become evident that these factors can frequently outweigh the thermodynamic and kinetic considerations [9]. It is widely recognized that the corrosion of carbon steel in aerated neutral solutions may be accounted for by the anodic reaction as in Eq. (1) and cathodic reaction in presence of oxygen:

$$
1 / 2 \mathrm{O}_{2}+\mathrm{H}_{2} \mathrm{O}+2 \mathrm{e}^{-} \rightarrow 2 \mathrm{OH}^{-}
$$

In general, as the corrosion proceeds, the process becomes more complex due to building up of corrosion products which restrain the oxygen transport to the surface, growth of the surface roughness which increases the momentum 
and mass transport between surface and solution, changing physico-chemical properties of the corrosion products; and changing mechanics of flow. The formation of corrosion product layer has a noticeable effect of the corrosion rate of the metal depending on the solution nature and on the temperature and hydrodynamics $[10,11,12]$.

The aim of this work is to study the influence of velocity, temperature, corrosion products layer (or time) on the corrosion rate and corrosion potential of commercial steel pipe in different concentrations of $\mathrm{Na}_{2} \mathrm{SO}_{4}$ solutions.

\section{Experimental Work}

Figure (1) shows the experimental apparatus that was used to perform the experimental work. It was composed of stirrer to obtain different rotational velocities, water bath to obtain different solution temperatures, power supply to provide a constant applied voltage between the electrodes, digital ammeter to measure the current, digital voltmeter to measure the potential, variable resistance (rheostat) to control the current flow, electrical connection between cathode (specimen) and the cell. Also, air pump to pump the air through the solution, oxygen meter to measure the solubility of oxygen in solution in ppm, $\mathrm{pH}$ meter to monitor the $\mathrm{pH}$ of the solution, and conductivity meter to measure the electrical conductivity of the solution. Cylindrical carbon steel specimen was prepared to fit the specimen holder with a surface area having a dimensions of $30 \mathrm{~mm}$ long (L), $22 \mathrm{~mm}$ inside diameter $\left(\mathrm{d}_{\mathrm{i}}\right)$, and $25 \mathrm{~mm}$ outside diameter $\left(\mathrm{d}_{\mathrm{o}}\right)$. It serves as a cathode.

Before each experiment, the carbon steel specimen (working electrode) was polished with 120, 180, 220, 400 and 2000 grit silicon carbide paper, washed with brushing by plastic brush with running tap water, immersed in ethanol for 30 second dried with clean tissue, and then dried by using electrical 
oven to temperature of about $110{ }^{\circ} \mathrm{C}$ for 10 minute. The specimen then was stored in vacuum desiccator over high activity silica gel until use.

In weight loss experiments, after the specimen was kept in the dissector to cool, it then was weighted to nearest $0.1 \mathrm{mg}\left(\mathrm{w}_{1}\right)$ by using digital balance of high accuracy ( 4 decimal places of gram) to measure the weight loss. Then the specimen was exposed to corrosion environment for $4 \mathrm{~h}$. At the end of weight loss experiment, the specimen was washed by tap water with brushing to remove the corrosion products that formed on the outside surface and then immersed in $10 \%$ hydrochloric acid containing chemical inhibitor (thioharnstoff) for 30 second $[13,14]$. Blank tests showed no appreciable weight loss caused by cleaning with inhibited acidic solution. After that the specimen was washed by tap water, distilled water, dried with clean tissue, rinsed in ethanol and dried by using electrical oven to a temperature about $110{ }^{\circ} \mathrm{C}$ for 10 minutes. Then the specimen was kept in the dissecator to cool and then weighted $\left(\mathrm{w}_{2}\right)$. So that the corrosion rate can be determined using:

$$
\mathrm{CR}=\frac{\Delta W}{\mathrm{~A} \times \mathrm{t}}
$$

And the limiting current density can be determined by using the following equation:

$$
\mathrm{i}_{\mathrm{L}}=\mathrm{zF} \mathrm{N} \mathrm{N}_{\mathrm{O}}
$$

$\mathrm{N}_{\mathrm{O} 2}$ is the molar flux of oxygen which is defined as the moles of $\mathrm{O}_{2}$ reacted per unit area per unit time $\left(\mathrm{gmol} / \mathrm{m}^{2} \cdot \mathrm{s}\right)$. Also, according to reactions 1 and $3, \mathrm{~N}_{\mathrm{O} 2}=$ $0.5 \mathrm{~N}_{\mathrm{Fe}}$.

In polarization experiments, the counter (auxiliary) electrode was made of graphite which serves as anode. The surface area of the counter electrode was made larger than that of the working electrode $(\mathrm{Aa} / \mathrm{Ac}=2.7)$ to ensure that the 
limiting current density occurs on the cathode rather than anode $[15,16]$. Salt bridge connected to standard calomel electrode (SCE) was used as reference electrode employed to measure the potentials. The luggin capillary of the reference electrode was placed $2 \mathrm{~mm}$ downstream of the working electrode. The electrical connection between the circuit and the rotating specimen was attained by using graphite brush.

To investigate the effect of time on the corrosion rate, in polarization measurements after the solution had reached the desired temperature, the electrical circuit was switched on where maximum current pass through the cell because the resistance equals to zero. The specimen was cathodically polarized from a potential of nearly $-1.4 \mathrm{~V}$ (vs. SCE) to the corrosion potential (where $\mathrm{i}_{\text {app }}$ $=0$ ) at a rate of $5-10 \mathrm{mV}$ by changing the applied current using rheostat, i.e. 5 $\mathrm{mV}$ when the change of current with potential is high (near corrosion potential) and $10 \mathrm{mV}$ when the change of current with potential is low, i.e. in the limiting current density region. The current was recorded for step changes in potential. Two minutes were allowed for steady state to be reached after each potential increment $[11,15]$. For the experiments with air bubbling, the air is pumped using air pump for 15 minutes before each run and the bubbling is kept until the end of the run. The oxygen concentration was measured for each condition using dissolved oxygen meter. After collecting the data by recording the current and potential, polarization curve can be drawn by using semi log scale where the $\mathrm{x}$-axis represents the current density (log scale) and the y-axis represents the potential. So that the limiting current density can be obtained from this curve. Method proposed by Gabe and Makanjoula [16] was adopted to determine the limiting current.

The obtained values of $i_{L}$ represent values for clean surface $(t=0)$, i.e. no corrosion products were formed, since during the polarization experiment no free corrosion occurred (except at low currents near the corrosion potential) 
because the specimen was cathodically protected. To investigate the influence of time on the instantaneous corrosion rate, the electrical circuit was switched off and the specimen was allowed to corrode freely at a particular velocity and temperature. A free corrosion of the specimen continues for $1 \mathrm{~h}$ during this interval corrosion proceeds and the corrosion product forms on the surface of the specimen. At the end of $1 \mathrm{~h}$, the electrical circuit was again switched on and the specimen was polarized to $-1.4 \mathrm{~V}$ (vs. SCE) and polarization experiment was repeated to obtain the complete polarization curve and new $i_{L}$. This value of $\mathrm{i}_{\mathrm{L}}$ represents the value at $\mathrm{t}=1 \mathrm{~h}$. At the end of the second polarization measurement, the electrical circuit was switched off while the specimen was kept corroding in the solution for another $1 \mathrm{~h}$. During this second interval, the specimen will undergo a free corrosion forming additional corrosion products. The specimen was then polarized to $-1.4 \mathrm{~V}$ (vs. SCE) by switching on the electrical circuit again to repeat the polarization experiment and to obtain new $\mathrm{i}_{\mathrm{L}}$ at $\mathrm{t}=2 \mathrm{~h}$. Each run was carried out in duplicate with third run when the reproducibility was in doubt. The solubility of oxygen at different velocities, temperatures, and salt concentration was measured in ppm at each 15 min using dissolved oxygen meter.

\section{Results and Discussions}

Figure (2) shows the corrosion rate obtained from weight loss experiments expressed in gmd in $0.2 \mathrm{M} \mathrm{Na}_{2} \mathrm{SO}_{4}$ versus rotational velocity. From Figure (2) it is clear that increasing flow velocity leads to an increase in corrosion rate. It can be seen that the corrosion rate increases from 26 gmd to 118 gmd $(350 \%)$ when the rotational velocity increased from 0 to $2000 \mathrm{rpm}$. This increasing is due to the increase in oxygen transport toward the surface because the rate of oxygen reduction reaction is generally limited by the speed at which oxygen can reach the surface of the metal. Previous studies $[9,11,17$, 
18] indicated the greater turbulence due to high velocities results in more uniform $\mathrm{O}_{2}$ concentration near the surface. It is to be noted from Figure (2) that when the rotational increased from $1500 \mathrm{rpm}$ to 2000 there is no increase in the corrosion rate. This the behavior can be interpreted as follows: when the velocity increase, the transport of $\mathrm{O}_{2}$ increases toward the surface with increasing velocity. At high velocities the rate of oxygen transport to the surface becomes higher or equal to the rate of $\mathrm{O} 2$ consumption on the surface, therefore further increase in the velocity has no effect to increase the corrosion rate.

Figures (3-5) show the polarization curve for carbon steel corrosion for different rotational velocities in $0.2 \mathrm{M} \mathrm{Na}_{2} \mathrm{SO}_{4}$ at 32,42 , and $52{ }^{\circ} \mathrm{C}$ respectively. It is clear that the current reaches the limiting value when the potential approaches the $\mathrm{H}_{2}$ evolution potential. In addition, the higher the velocity is the higher the $i_{L}$ will be. It should be noted from Figs. 3 to 5 that the limiting current density region is not clear for the case of zero rotational velocity (static conditions), where, th 4 larization curve is not too steep and hence the limiting current cannot be obtained, i.e. the polarization technique fails to determine the corrosion rate. This behavior can be reasoned to the fact that for stationary conditions the corrosion potential is relatively low, therefore the limiting current occurs near the hydrogen evolution region. Hence,, no oxygen limiting current appears due to the generation of other reduction reactions currents such as the hydrogen reduction currents. In such cases, the weight loss method must be adopted. Figure (6) shows the effect of velocity and temperature on $i_{L}$, From this figure it is clear that increasing the velocity leads to an increase in the limiting current density. The average increase in the $\mathrm{i}_{\mathrm{L}}$ with the velocity for the three temperatures is about $200 \%$ for a velocity range from $250 \mathrm{rpm}$ to $2000 \mathrm{rpm}$. The increase in the $i_{L}$ because the increase in the transport of oxygen to the metal surface [ 18,9]. Examining literature reveals 
a variety of $i_{L}$ dependence on flow velocity that was found by authors for various geometries. The manner in which velocity affects the limiting diffusion current is a marked function of the physical geometry of the system. This dependence depends on the nature of the system under consideration, i.e., geometry, roughness of the surface, viscosity, and temperature [9, 19, 20, 21]. From this figure, it can be seen that the corrosion rate at $42^{\circ} \mathrm{C}$ is higher than at $32{ }^{\circ} \mathrm{C}$ and $52{ }^{\circ} \mathrm{C}$; also, the corrosion rate at $52{ }^{\circ} \mathrm{C}$ is higher than at $32{ }^{\circ} \mathrm{C}$. The effect of temperature on the corrosion rate for mass transfer control systems is represented by changing two parameters affecting the corrosion rate in conflicting ways that are the $\mathrm{O}_{2}$ solubility and diffusivity. The corrosion rate at $42{ }^{\circ} \mathrm{C}$ is higher than $52{ }^{\circ} \mathrm{C}$ can be ascribed to the lower concentration of $\mathrm{O}_{2}$ at $52^{\circ} \mathrm{C}$ than $42^{\circ} \mathrm{C}$. Increasing the temperature will increase the rate of oxygen diffusion to the metal surface by decreasing the viscosity of water enhancing the corrosion rate. On the other hand, increasing temperature decreases the oxygen solubility the factor that restrains the corrosion [19,22]. Table (1) shows the experimentally measured solubility of oxygen $\left(\mathrm{C}_{\mathrm{b}}\right)$ in ppm by using oxygen meter at various sodium sulphate concentrations. From the table it is clear that at a given temperature, increasing the dissolved salt $\left(\mathrm{Na}_{2} \mathrm{SO}_{4}\right)$ concentration leads to a decrease in the $\mathrm{O}_{2}$ concentration. Also, the temperature has an effect on the solubility of oxygen at constant salt concentration, that is, increasing the temperature leads to a significant decrease in the $\mathrm{O}_{2}$ concentration. Table 2 shows the solubility of oxygen $\left(\mathrm{C}_{\mathrm{b}}\right)$ in $0.2 \mathrm{M} \mathrm{Na}_{2} \mathrm{SO}_{4}$ solution with air bubbling under different conditions. It is clear that adding air bubbles lead to an increase in the $\mathrm{O}_{2}$ concentration at constant salt concentration and temperatures, also, increasing velocity leads to an increase in the $C_{b}$ when pumping the air in the solution because the velocity will increase the turbulence by eddy diffusion and increase the distribution of bubbles within the solution and hence more $\mathrm{O}_{2}$ transfer to the solution. Also increasing the temperature for a constant salt 
concentration and velocity leads to a decrease in $\mathrm{C}_{\mathrm{b}}$ because the escape of $\mathrm{O}_{2}$ from the solution to atmosphere. Figure (7) shows the effect of rotational velocity on the limiting current density in presence of air bubbling. Comparing Figure (7) with Figure (6) indicates that adding air bubbles to the electrolytic solution leads to an increase in the $\mathrm{i}_{\mathrm{L}}$ (the corrosion rate) for certain temperature and velocity due to the increased $\mathrm{O}_{2}$ concentration. The Figure (7) reveals that, for all velocities, $\mathrm{i}_{\mathrm{L}}$ at $42{ }^{\circ} \mathrm{C}$ is higher than that at $32{ }^{\circ} \mathrm{C}$ and $52{ }^{\circ} \mathrm{C}$. Also $\mathrm{i}_{\mathrm{L}}$ at 52 ${ }^{\circ} \mathrm{C}$ is higher than $32{ }^{\circ} \mathrm{C}$. This behavior of corrosion rates indicates that the combined effect of $\mathrm{O}_{2}$ solubility and molecular diffusivity is highest at $42{ }^{\circ} \mathrm{C}$ followed by $52{ }^{\circ} \mathrm{C}$ and $32{ }^{\circ} \mathrm{C}$, i.e. at $42{ }^{\circ} \mathrm{C}$ the effect of these two parameters on the corrosion rate is maximum. The increase in corrosion rate when the velocity increased from $250 \mathrm{rpm}$ to $2000 \mathrm{rpm}$ in presence of air bubbles is $420 \%$ at 32 ${ }^{\circ} \mathrm{C}, 260 \%$ at $42{ }^{\circ} \mathrm{C}$, and $450 \%$ at $52{ }^{\circ} \mathrm{C}$. Comparing these values with that in Figure (6) (no $\mathrm{O}_{2}$ bubbling) indicates that the presence of $\mathrm{O}_{2}$ leads to appreciable increase in the effect of velocity on the corrosion rate. Figure (8) shows the experimentally measured electrical conductivity of the solution for different salt concentrations at various temperatures using digital electrical conductivity meter. It is clear that increasing salt concentration leads to an increase in the conductivity of the solution at constant temperature. Also, the higher the temperature is the higher conductivity will be. Figure (9) shows the effect of sodium sulphate concentrations on the $i_{L}$ at $750 \mathrm{rpm}$. It is clear that increasing $\mathrm{Na}_{2} \mathrm{SO}_{4}$ concentration from 0.01 to $0.1 \mathrm{M}$ leads to an increase in $\mathrm{i}_{\mathrm{L}}$ from 5.75 to $9 \mathrm{~A} / \mathrm{m}^{2}(56 \%)$ at $32{ }^{\circ} \mathrm{C}$, from 9 to $12.5 \mathrm{~A} / \mathrm{m}^{2}(40 \%)$ at $42{ }^{\circ} \mathrm{C}$, and from 7.75 to $11 \mathrm{~A} / \mathrm{m}^{2}(42 \%)$ at $52{ }^{\circ} \mathrm{C}$. Beyond this concentration, the $\mathrm{i}_{\mathrm{L}}$ shows a considerable decrease at all temperatures. This behavior can be attributed to the increased electro-conductivity because of the increased salt content, until the salt concentration is great enough to cause an appreciable decrease in the oxygen solubility, resulting in a decrease in the rate of depolarization. The same 
trend was noticed in previous works for corrosion in $\mathrm{NaCl}$ solution [23]. Peralta et al. [6] stated that the mechanism of corrosion attack in sulphate solutions occurring on the surface of the mild steel after a certain exposure can be regarded as partially uniform. This attack started in isolated locations and spread laterally without developing any pits. The effect of $\mathrm{SO}_{4}^{-2}$ on the rate of oxidation of iron in mildly alkaline solutions results from its ability to form soluble complexes with $\mathrm{Fe}^{+2}$ or $\mathrm{Fe}^{+3}$ ions. Also, it is found that sulphate ions accelerate the active dissolution of iron and the films formed in sulfate solutions resulted from supersaturated solutions of iron salts, most probably iron hydroxysulfate. This implies that iron dissolves in sulphate solutions at a high rate, creating a supersaturated solution and allowing precipitation of a non protective film . Figure (10) shows the polarization curves for $\mathrm{u}=250 \mathrm{rpm}$ at temperature of $32{ }^{\circ} \mathrm{C}$ and in $0.2 \mathrm{M} \mathrm{Na}_{2} \mathrm{SO}_{4}$ solution at different time intervals. It is evident that the $i_{L}$ decreases with time due to the continuous growth of the corrosion product layer (fouling layer) which decreases the transport of $\mathrm{O}_{2}$ to metal surface and the activity of the surface and hence the corrosion rate [19, 24]. Figure (11) shows the effect of time on the $i_{L}$ at the three temperatures for velocity of $250 \mathrm{rpm}$. It can be seen from this figure that the $i_{L}$ decreases with time for the three temperature. The highest decrease is in the case of $\mathrm{T}=42{ }^{\circ} \mathrm{C}$ which is up to $55 \%$ after $2 \mathrm{~h}$. The decrease in the corrosion rates in $32{ }^{\circ} \mathrm{C}$ and $52 \mathrm{C}$ are $45 \%$ and $40 \%$ respectively. At time zero, where no corrosion products are found, the corrosion rate $\left(i_{L}\right)$ at $42{ }^{\circ} \mathrm{C}$ is highest, while, at $32{ }^{\circ} \mathrm{C}$ and $52{ }^{\circ} \mathrm{C}$, the corrosion rates are comparable. At times of $1 \mathrm{~h}$ and $2 \mathrm{~h}$, the corrosion rate of $32{ }^{\circ} \mathrm{C}$ still lower but the corrosion rates at $42{ }^{\circ} \mathrm{C}$ and $52{ }^{\circ} \mathrm{C}$ are comparable. This trend indicates that the effect of corrosion product formation (fouling) to decrease the corrosion rate is highest at $42{ }^{\circ} \mathrm{C}$. Also, the rise in temperature contributes to increase the porosity (or decrease the density) of corrosion products layer and that facilitates the passage of $\mathrm{O}_{2}$ toward the surface $[11,19]$. 
That is why the effect of corrosion products to decrease the corrosion rate at 32 ${ }^{\circ} \mathrm{C}$ and $42{ }^{\circ} \mathrm{C}$ is higher than in $52{ }^{\circ} \mathrm{C}$. Figure (12) shows the effect of time on the $i_{L}$ at the three different velocities 250, 1000, $2000 \mathrm{rpm}$ at temperature of 32 ${ }^{\circ} \mathrm{C}$. The figure indicates that the formation of corrosion products with time decreases $i_{L}$ for all values of velocity. It can be noted that for low $u, i_{L}$ slightly decreases with time. As $u$ increases, the decrease in $i_{L}$ with time becomes higher at first time interval (after $1 \mathrm{~h}$.). After $2 \mathrm{~h}$ the decrease is slight. The decrease in the corrosion rate (i.e. $i_{L}$ ) with time for velocity of $250 \mathrm{rpm}$ is about $30 \%$, for $1000 \mathrm{rpm}$ is $35 \%$, for $2000 \mathrm{rpm}$ is $55 \%$. Hence, the higher the velocity is the higher the decrease in the corrosion rate due to high amount of corrosion products formed which in turn restrains the arrival of dissolved $\mathrm{O}_{2}$ to the surface. This indicates the important inhibitive effect of this fouling layer to decrease the corrosion. Examining literature findings reveals that there are different trends of corrosion rate with formation of corrosion product. The studies of Mahato et. al., [12, 19, 25] for pipe flow, indicated that the corrosion rate always decreases with time. Slaiman and Hasan [11] for pipe flow noticed that at low temperatures the formation of corrosion product leads to a decrease in the corrosion rates even at high velocities, but at high temperature and high flow velocities, the formation of corrosion product leads to increase the corrosion rate. Figure (13) shows the effect of time on the $i_{L}$ at the three temperatures for velocity of $250 \mathrm{rpm}$ with air bubbling. The figure reveals that at $32{ }^{\circ} \mathrm{C}, \mathrm{i}_{\mathrm{L}}$ decreases with time due to the formation of corrosion product. While for high temperature $42{ }^{\circ} \mathrm{C}$ and $52{ }^{\circ} \mathrm{C}$, $\mathrm{i}_{\mathrm{L}}$ steeply decreases at first hour then it has slight decrease with time because of the corrosion rate is higher at first hour than second hour. Figure 14 shows the effect of time on the $i_{L}$ at the three velocities $(250,750,2000 \mathrm{rpm})$ at temperature of $32{ }^{\circ} \mathrm{C}$ in presence of air bubbles. Figure (14) shows the same behavior of $i_{L}$ with time at different 
velocities as in figure (13) but with a significant increase in the exchange current density due to addition of air bubbles.

Figures (15-17) show comparison of the variation of $i_{L}$ with time in presence and absence of air bubling. It is evident that the bubbling has noticeabl effect on the corrosion rate $\left(i_{L}\right)$ for all temperatures. The corrosion rate at $32{ }^{\circ} \mathrm{C}$ exhibits highest increase of $i_{L}$ with air bubbling where it ranges from 10 percent at time zero to 50 percent at time $2 \mathrm{~h}$. Howerver, the other two temperatures give lower increase in the corrosion rate, i.e for $42{ }^{\circ} \mathrm{C}$ the increase ranges from 10 pecent to 15 and, for $52{ }^{\circ} \mathrm{C}$ it ranges from 16 percent to 10 percent. The behavior can be interpreted in reference to Table 1 where the increase in $\mathrm{O}_{2}$ solubility with air bubbling is highest for $42^{\circ} \mathrm{C}$ causing highest increase in the corrosion rate. Figure (18) shows the effect of rotational velocity on the corrosion potential in $0.2 \mathrm{M} \mathrm{Na}_{2} \mathrm{SO}_{4}$ solution. Figure (19) shows the effect of velocity and temperature on the corrosion potential $\left(E_{c}\right)$ in $0.2 \mathrm{M} \mathrm{Na}_{2} \mathrm{SO}_{4}$ in presence of air bubbles. In both figures, it is clear that the corrosion potential is shifted to more positive values with increasing rotation velocity. In addition there is considerable increase of $E_{c}$ with the temperature in case of air bubbling Figure (19). This indicates that the high concentration of $\mathrm{O}_{2}$ leads to an increase in the effect of temperature on $E_{c}$. Therefore, the corrosion potential in aerated and oxygen-saturated solutions is flow dependent since the cathodic process, i.e., oxygen reduction reaction, is mass transfer controlled. This behavior is in agreement with previous findings [26, 27, 24, 28 ]. Ross et. al. [29] stated that the increase in $\mathrm{E}_{\mathrm{c}}$ with velocity is due to the increase in oxygen transport to the metal surface and when the system is free from oxygen, the velocity has no effect on $E_{c}$. 


\section{Conclusions :}

The corrosion rate of carbon steel represented by limiting current density in sodium sulphate increases with increasing rotation velocity and have complex trend with temperature and oxygen concentration. For the range of temperature from 32 to $52{ }^{\circ} \mathrm{C}$, the corrosion rate increases three times (as an average) when the rotational velocity increases from 0 to $2000 \mathrm{rpm}$. When air is bubbled in $\mathrm{Na}_{2} \mathrm{SO}_{4}$ solution the $\mathrm{O}_{2}$ concentration increases slightly causing an appreciable increase in the corrosion rate. The consequent increase in the corrosion rate ranges from $10 \%$ percent to $50 \%$ depending on the rotational velocity and solution temperature. In addition, the increase in the $\mathrm{O}_{2}$ concentration shifts the corrosion potential considerably to more positive direction. The corrosion rate at $42{ }^{\circ} \mathrm{C}$ is higher than that at $32{ }^{\circ} \mathrm{C}$ and $52{ }^{\circ} \mathrm{C}$ in presence and absence of air bubbles. The corrosion rate increases by $40 \%$ to $55 \%$, depending on the temperature, with increasing $\mathrm{Na}_{2} \mathrm{SO}_{4}$ concentrations up to $0.1 \mathrm{M}$ and then the it decreases mainly due to the decrease in $\mathrm{O}_{2}$ concentration with further increase in $\mathrm{Na}_{2} \mathrm{SO}_{4}$ concentration. The time has a noticeable effect on the corrosion rate due to the formation of corrosion product layer (fouling layer). The formation of this layer causes reduction in corrosion rate by $40 \%$ to $55 \%$ depending on the temperature and rotational velocity. For the case of air bubbling at $32{ }^{\circ} \mathrm{C}$, the reduction in the corrosion rate with time ranges between $30 \%$ to $55 \%$ indicating that this layer plays important role in corrosion mitigation corrosion. 


\section{References:}

1. Bornstein N. S. and M. A. Decrescente, Metall. Trans. 2, 2875 (1971).

2. Goebel J. A, F. S. Pettit and G. W. Goward, "Oxygen Scavengers" Metall. Trans., 4, 261 (1973).

3. Stringer J., "Hot Corrosion in Gas Turbines," ASM International, High Temperature Corrosion and Materials Application, chapter 9, pp. 249258,2007

4. Huijbregts W., "Acid Corrosion Resistance of Boiler Steels." Materials Performance. pp. 23-27, 2007.

5. Fouda A.S., G.Y. Elewady and M. N. El-Haddad, "Corrosion Inhibition of Carbon Steel in Acidic Solution Using Some Azodyes" Canadian Journal on Scientific and Industrial Research Vol. 2, No. 1, January 2011.

6. Peralta S. A., J. G. Llongueras , M. P. Pardavé \& M. R. Romo, "Study of the electrochemical behaviour of a carbon steel electrode in sodium sulfate aqueous solutions using electrochemical impedance spectroscopy”, Journal of Solid State Electrochemistry Springer-Verlag, May 2002.

7. Smith S. W., K.M. McCabe, and D. W. Black 'Effect of Flow Parameters on the Cathodic Protection of A steel Plate in Natural Seawater", Corrosion, vol. 45, No.10, pp.790- 793 October 1989.

8. Shreir L.L., R.A. Jarman \& G.T. Burstein "Corrosion Metal / Environment Reactions" third edition, published by ButterworthHeinemann Volume I, Great Britain, 2000.

9. Brodkey, R. S. and H. C. Hershey, "Transport Phenomena", second edition, McGraw Hill, New York, 2007.

10.Slaiman Q. J. M. and Basim O. Hasan "Study on Corrosion Rate of Carbon Steel Pipe under Turbulent Flow Conditions" The Canadian Journal of Chemical Engineering Volume 88, December 2010. 
11. Mahato, B. K., F. R. Stewrd and L. W. Shimlit, "Steel Pipe Corrosion under Flow Condition - II. Mass Transfer Correlations with Temperature Effects," Corrs. Sci. J. 8, 737-749, 1968.

12.Fontana M.G. and N. D. Greene "Corrosion Engineering", 3rd edition, McGrawHall, London 1986.

13.Hasan, B. O., "Heat, Mass, and Momentum Analogies to Estimate Corrosion Rates under Turbulent Flow Conditions" Ph. D. Thesis Dept. of Chem. Eng., University of AL-Nahrain, Baghdad, 2003.

14.Pickett, D. J. and K. L. Ong, "The Influence of Hydrodynamic and Mass Transfer Entrance Effects on the Operation of a Parallel Plate Electrochemical Cell," Electchmica Acta 19, 875-881, 1974.

15.Gabe D.R. and P.A. Makanjoula, EFCF Publication Series No. 15, Electrochemical Eng., AICHE Symposium Series, No. 98, P.309, 1986.

16.Evans, U. R. and T. P. Haoar, "Electrochemical Mechanism of Atmospheric Rusting,” Proc. R. Soc. Lond. Ser. A 137, 343, 1932.

17.Foroulis Z. A. "The Influence of Velocity and Dissolved Oxygen on the Initial Corrosion Behavior of Iron in High Purity Water", Corrosion, Vol. 35, P. 340344, 1979.

18.Mahato, B. K., C. Y. Cha and W. Shemlit, "Unsteady State Mass Transfer Coefficients Controlling Steel Pipe Corrosion under Isothermal Flow Conditions," Corros. Sci. 20, 421-441, 1980.

19.Poulson, B., "Electrochemical Measurements in Flowing Solutions," Corrosion Sci. 23, 1, 391-408 (1983).

20.Stern M., "Fundamentals Electrode Processes in Corrosion," CorrosionNACE 13, 97-104 (1957).

21.Henry S.D and W.M. Scott "Corrosion in the Petrochemical Industry", $1^{\text {st }}$ edition, ASM International, USA, 1999. 
22.23-Revie R.W. and H. H. Uhlig, "Corrosion and Corrosion Control an Introduction to Corrosion Science and Engineering" fourth edition, published by John Wiley \& Sons, Inc., Hoboken New Jersey, 2008.

23.24-Makrides, A.C., J. Electrochem. Soc., vol. 107, P. 869, 1960.

24.25- Mahato, B. K., S. K. Voora 8 ' L. W. Shemilt, "Steel Pipe Corrosion under Flow Condition - an Isothermal Correlation for a Mass Transfer Model," Corros. Sci. 8, 173-193, 1968.

25.26-Hubbard, D. W. and E. N. Lightfoot, "Correlation of Heat and Mass Transfer Data for High Schmidt and Reynolds Numbers", Ind. Eng. Chem. 5, 370-379, 1966.

26.27-Nesic, N., B.F.M. Pots, J. Postlethwaite, and N. Trevenot, J. Corrosion Science and Eng., Ph. D. Study, Vol.1, Paper 3, 1995.

27.28-Chin, R.J., and K. Nobe, "Electrochemical aspects of Steel Corrosion in Sea Water", Corrosion J., Vol.33, P.364, 1977.

28.29-Ross, T.K., G.C. Wood, and I. J. Mahmud, "The Anodic Behavior of Iron Carbon Alloy in Moving Acid Media" Electrochem. Soc., Vol. 113, P.334, 1996. 


\section{Nomenclature:}
A: the area $=\pi^{*} d_{0} * L$ in $m^{2}$.
D: Diffusivity $\left(\mathrm{m}^{2} / \mathrm{s}\right)$
Ec: corrosion Potential (V)
t: time of exposure (hours)
V: Volts

$\Delta \mathrm{W}$ : the weight loss $=\mathrm{W}_{1}-\mathrm{W}_{2}$ in grams.

$i_{L}$ : limiting current density in $\mathrm{A} / \mathrm{m}^{2}$.

$\mathrm{i}_{\mathrm{c}}$ : corrosion current density, $\mathrm{A} / \mathrm{m}^{2}$

z: number of electron freed by corrosion reaction ( $\mathrm{z}$ for iron is 2 and for oxygen is 4 ).

F: Faradays constant (96487 columb/equivalent).

$\mathrm{C}_{\mathrm{b}}$ : the solubility of oxygen in $\left(\mathrm{mole} / \mathrm{m}^{3}\right)$.

CR: corrosion rate rpm: revolution per minute.

$\mathrm{u}$ rotational velocity in rpm.

$\mathrm{N}_{\mathrm{O} 2}$ : molar flux (mole $\left./ \mathrm{m}^{2} . \mathrm{s}\right)$.

$\mu$ : viscosity in $\mathrm{Kg} / \mathrm{m} \cdot \mathrm{sec}^{2}$.

$\rho:$ density in $\mathrm{kg} / \mathrm{m}^{3}$. 
Table 1: measured oxygen solubility in ppm at different sodium sulphate concentrations

\begin{tabular}{|c|c|c|c|}
\hline \multirow{2}{*}{$\begin{array}{c}\mathbf{N a} \\
\mathbf{4} \\
\text { concen } \\
\text { tration } \\
\mathbf{S} \\
\text { in } \mathbf{M}\end{array}$} & \multicolumn{3}{|c|}{$\mathbf{C}_{\mathbf{b}}, \mathbf{p p m}$} \\
\cline { 2 - 4 } & $\mathbf{3 2}{ }^{\mathbf{}} \mathbf{C}$ & $\mathbf{4 2}^{\mathbf{0}} \mathbf{C}$ & $\mathbf{5 2}^{\mathbf{}} \mathbf{C}$ \\
\hline $\mathbf{0 . 4}$ & 5.9 & 5.08 & 4.72 \\
\hline $\mathbf{0 . 2}$ & 6.2 & 5.32 & 4.94 \\
\hline $\mathbf{0 . 1}$ & 6.51 & 5.58 & 5.17 \\
\hline $\mathbf{0 . 0 5}$ & 6.85 & 5.84 & 5.41 \\
\hline $\mathbf{0 . 0 2 5}$ & 7.19 & 6.12 & 5.67 \\
\hline $\mathbf{0 . 0 1}$ & 7.56 & 6.41 & 5.93 \\
\hline
\end{tabular}

Table 2: measured oxygen solubility in ppm $(\mathrm{mg} / \mathrm{L})$ in $0.2 \mathrm{M} \mathrm{Na}_{2} \mathrm{SO}_{4}$ with addition of air bubbles.

\begin{tabular}{|c|c|c|c|}
\hline \multicolumn{3}{|c|}{$\mathbf{C}_{\mathbf{b}} \mathbf{p p m}$} \\
\cline { 2 - 4 } $\mathbf{T}^{\mathbf{0}} \mathbf{C}$ & $\mathbf{3 2}^{\mathbf{0}} \mathbf{C}$ & $\mathbf{4 2}^{\mathbf{0}} \mathbf{C}$ & $\mathbf{5 2}^{\mathbf{}} \mathbf{C}$ \\
\hline 0 & 7.34 & 6.54 & 5.97 \\
\hline 250 & 9.01 & 8.05 & 6.21 \\
\hline 750 & 10.5 & 8.21 & 6.58 \\
\hline 2000 & 12 & 8.89 & 6.95 \\
\hline
\end{tabular}

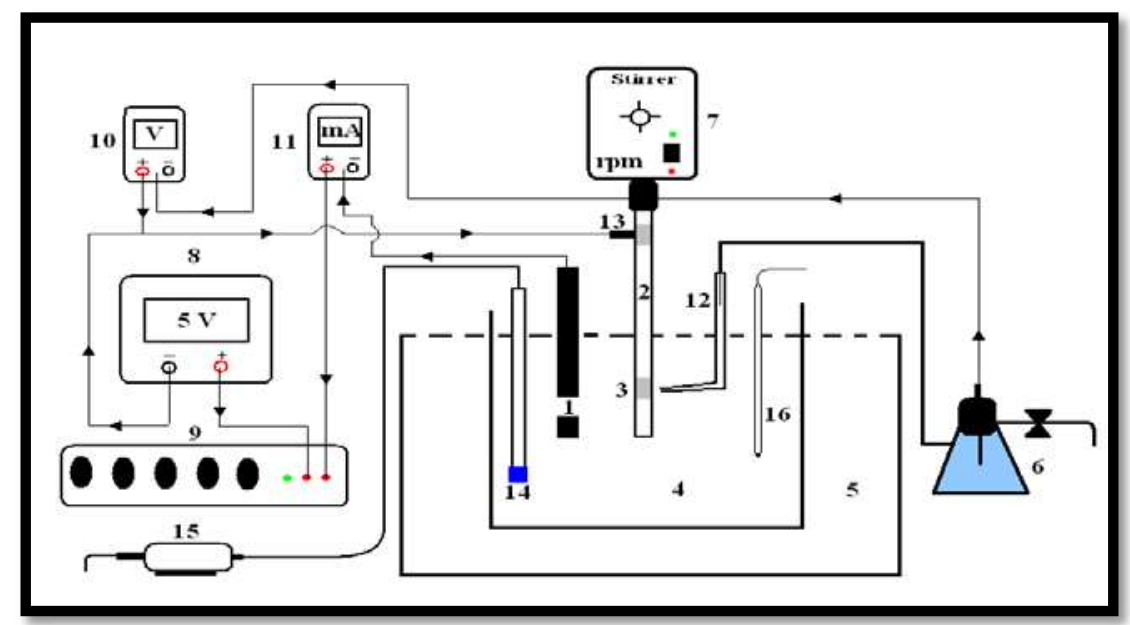

Fig. (1) Experimental apparatus.

1- graphite electrode (anode), 2- rotating shaft (holder), 3- working electrode (specimen), 4beaker , 5- water bath, 6- calomel electrode (reference electrode), 7- stirrer, 8- power supply, 9- resistance box, 10- voltmeter, 11-ammeter, 12- Luggin capillary, 13- brush 14- air distributer, 15- air pump, 16-thermometer. 


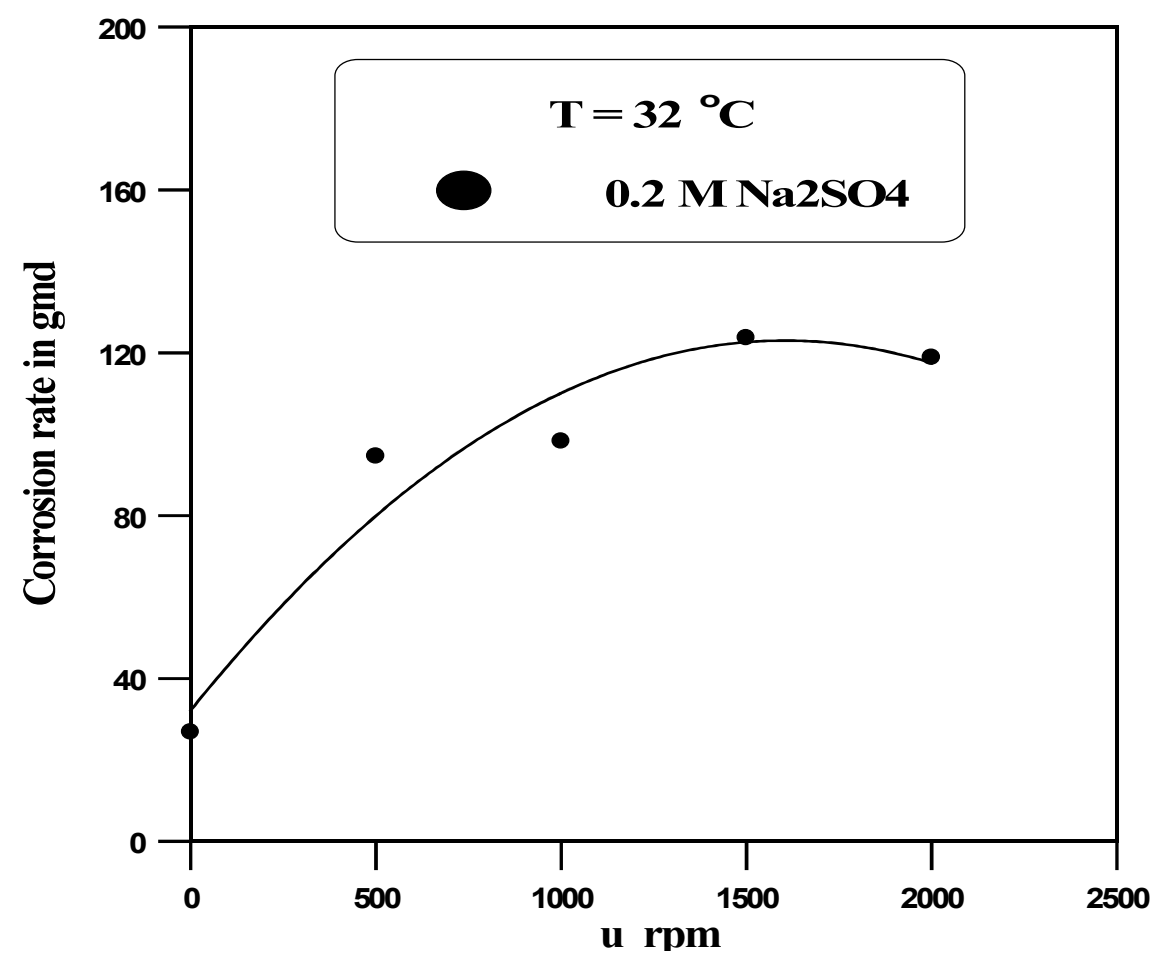

Fig. (2) Corrosion rate in $0.2 \mathrm{M} \mathrm{Na}_{2} \mathrm{SO}_{4}$ solution versus velocity at $32{ }^{\circ} \mathrm{C}$

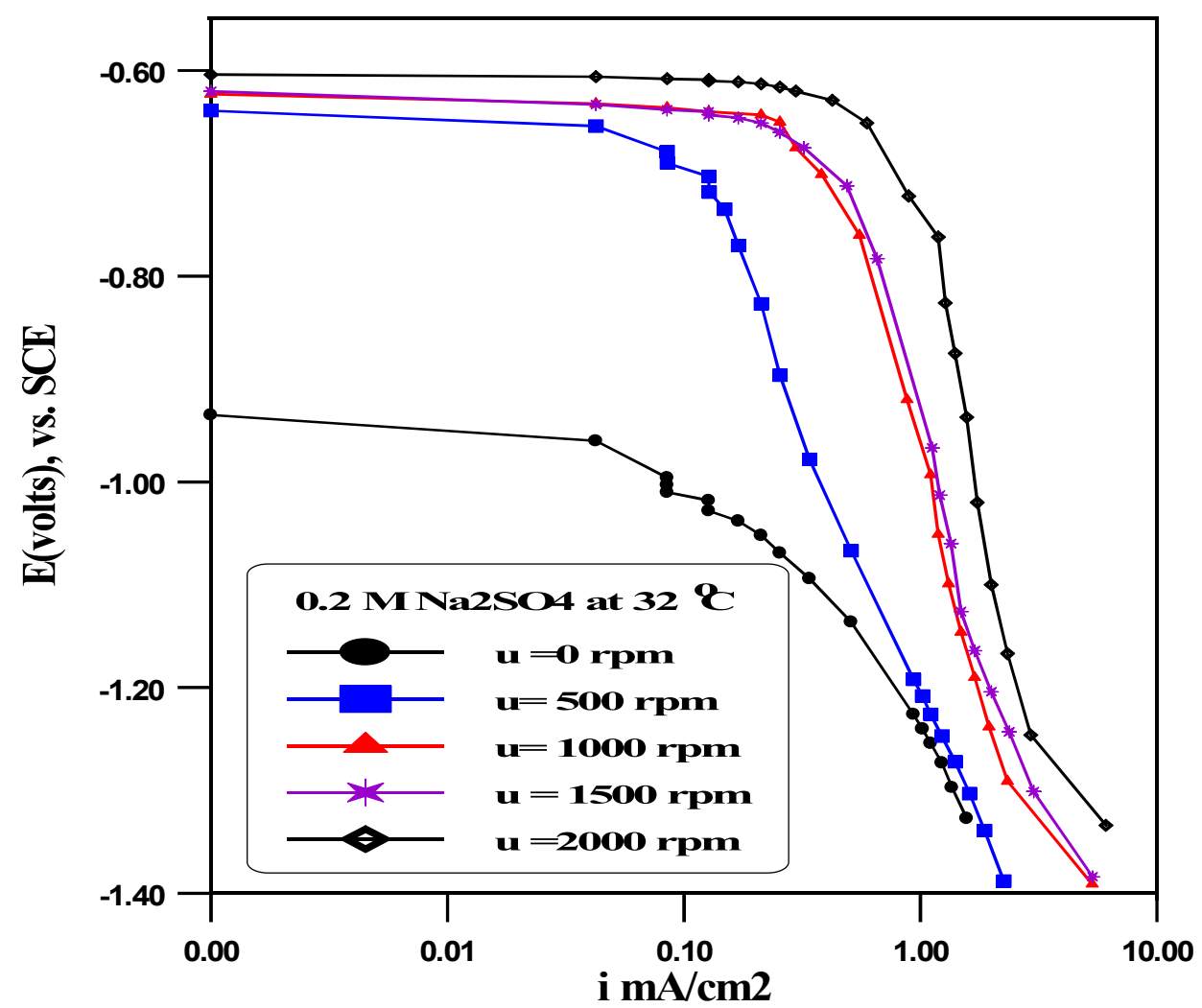

Fig. (3) Polarization curve at different velocity and $32{ }^{\circ} \mathrm{C}$. 


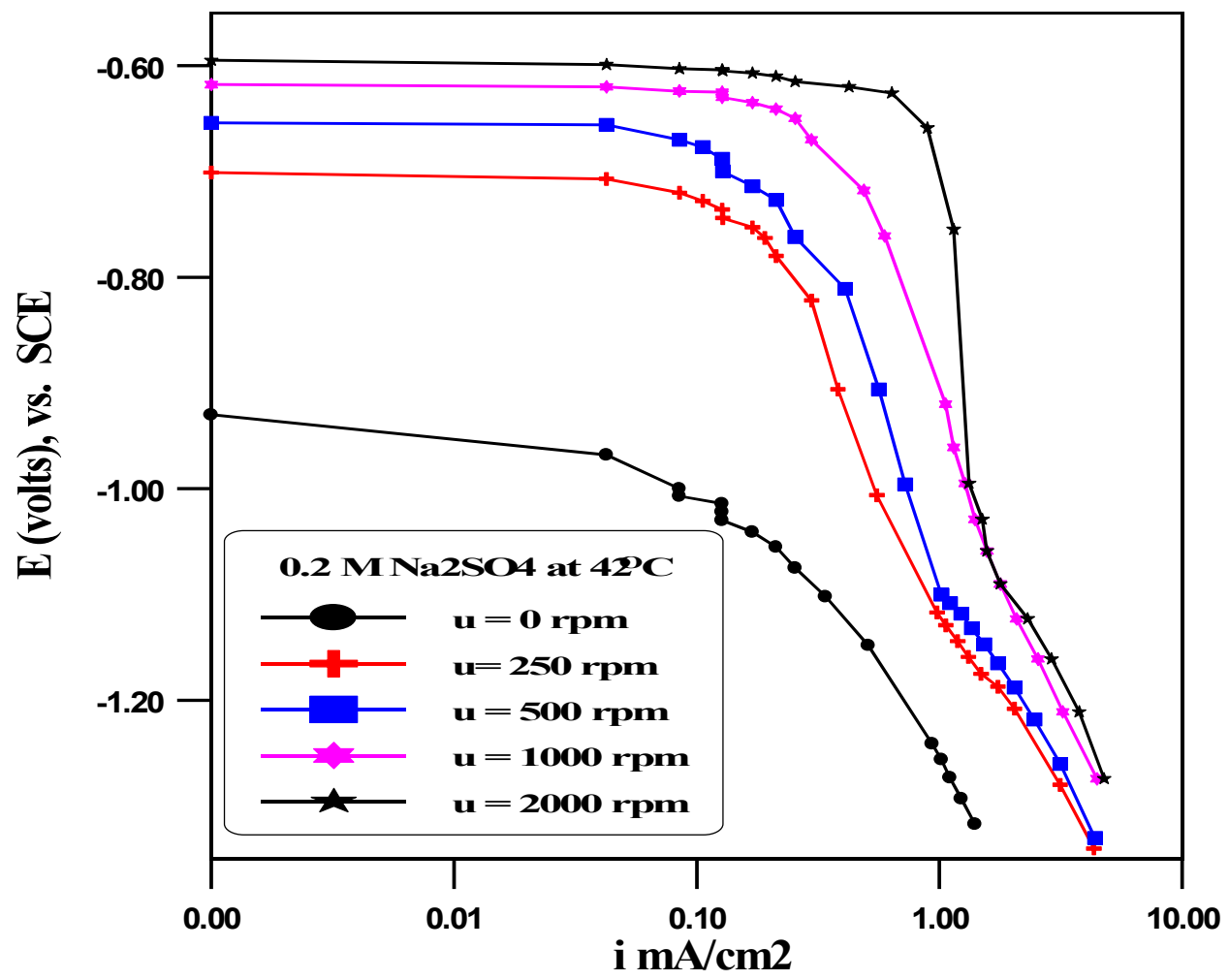

Fig. (4) Polarization curve at different Velocity and $42{ }^{\circ} \mathrm{C}$



Fig. (5) Polarization curve at different Velocity and $52{ }^{\circ} \mathrm{C}$ 




Fig. (6) Effect of velocity and temperature on $i_{L}$.

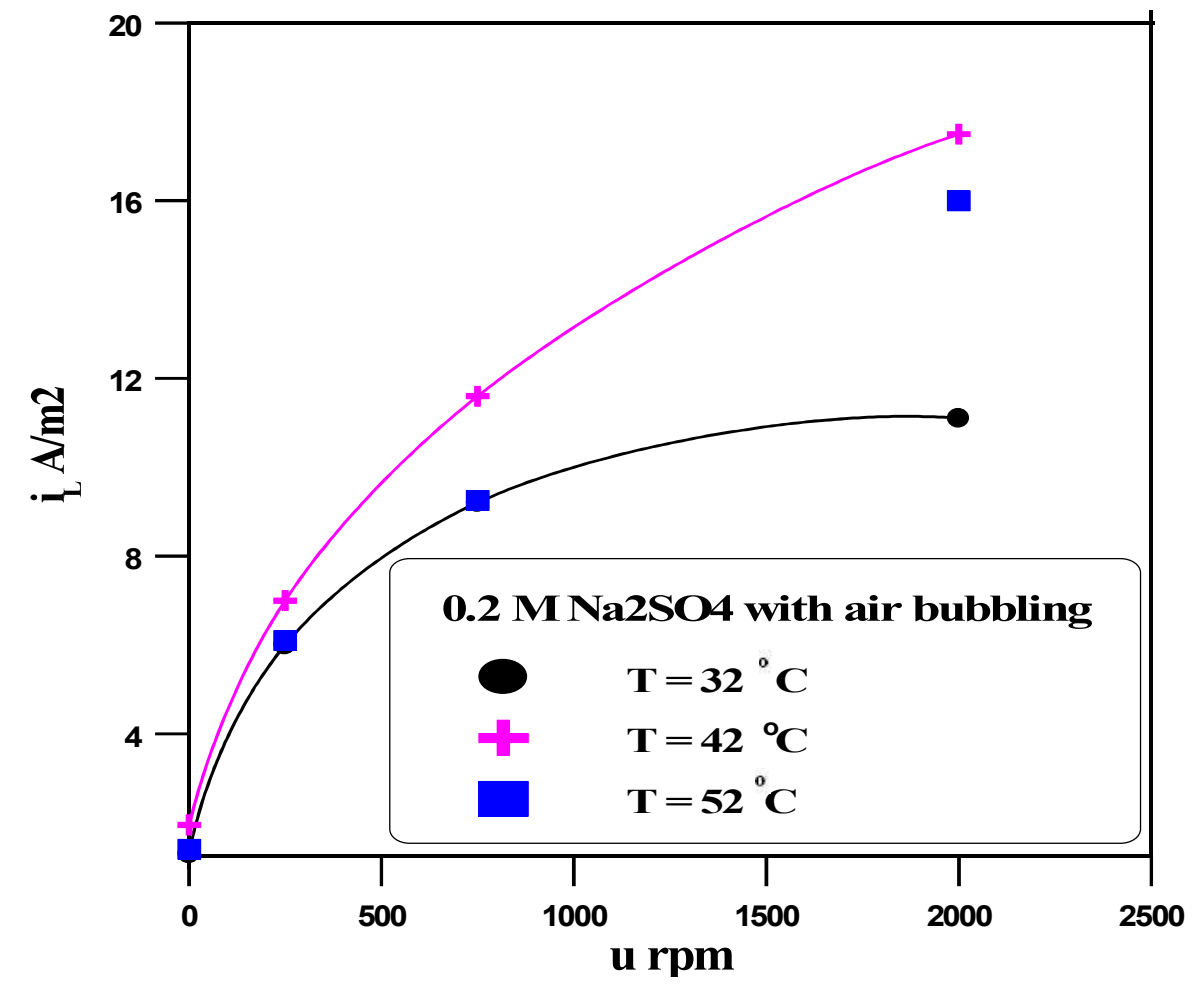

Fig. (7) Effect of velocity on $i_{L}$ with air bubbling at different temperatures 


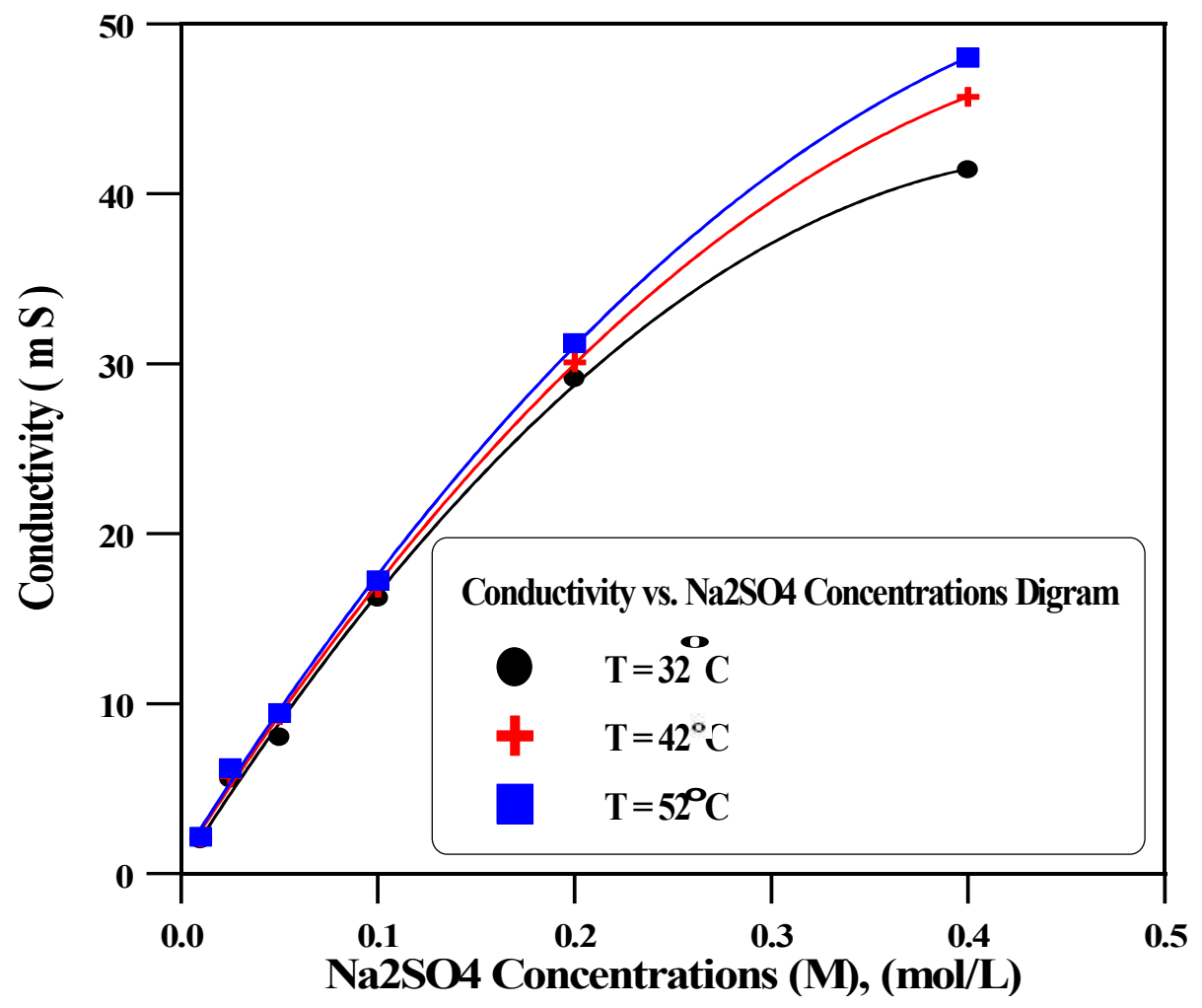

Fig. ( 8) Conductivity versus $\mathrm{Na}_{2} \mathrm{SO}_{4}$ concentrations.

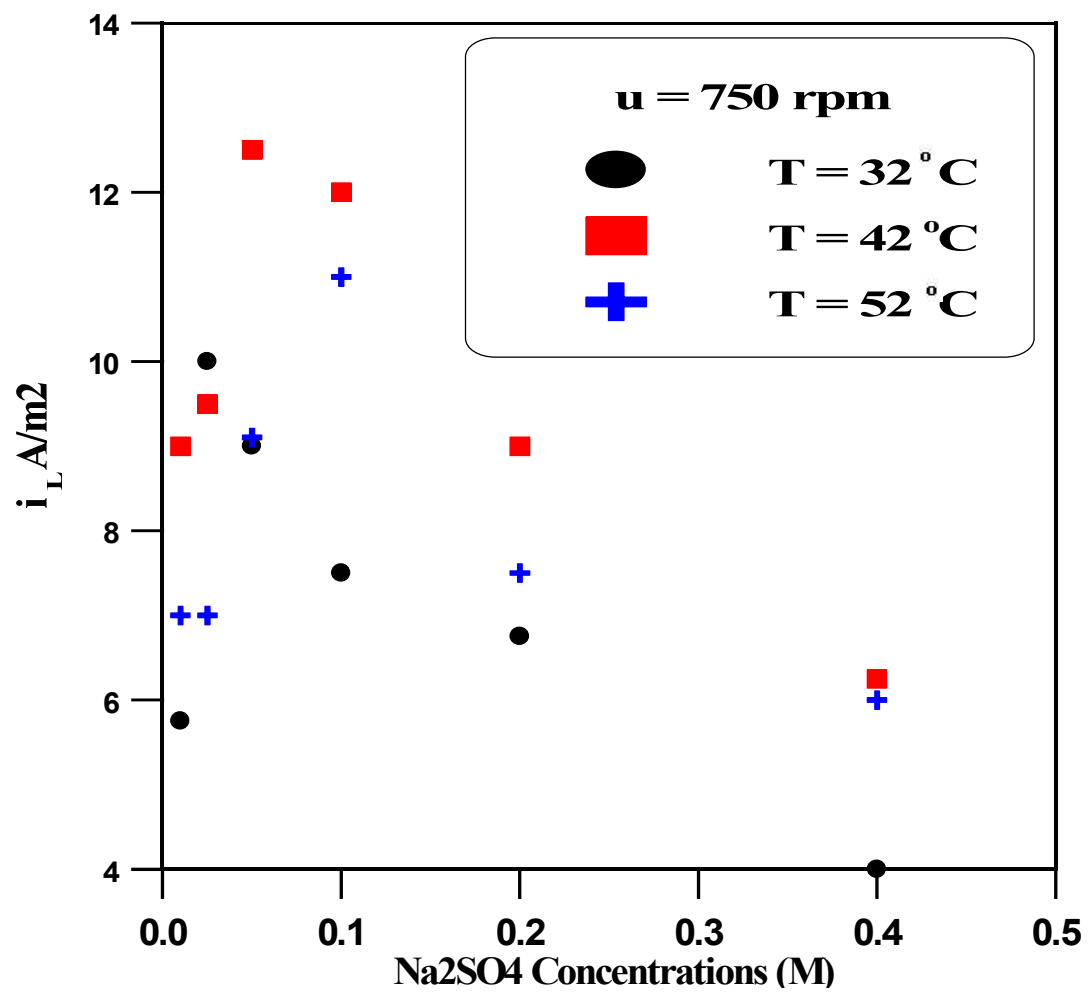

Fig. (9) Effect of different concentration of $\mathrm{Na}_{2} \mathrm{SO}_{4}$ and temperatures on $\mathrm{i}_{\mathrm{L}}$ at $750 \mathrm{rpm}$. 


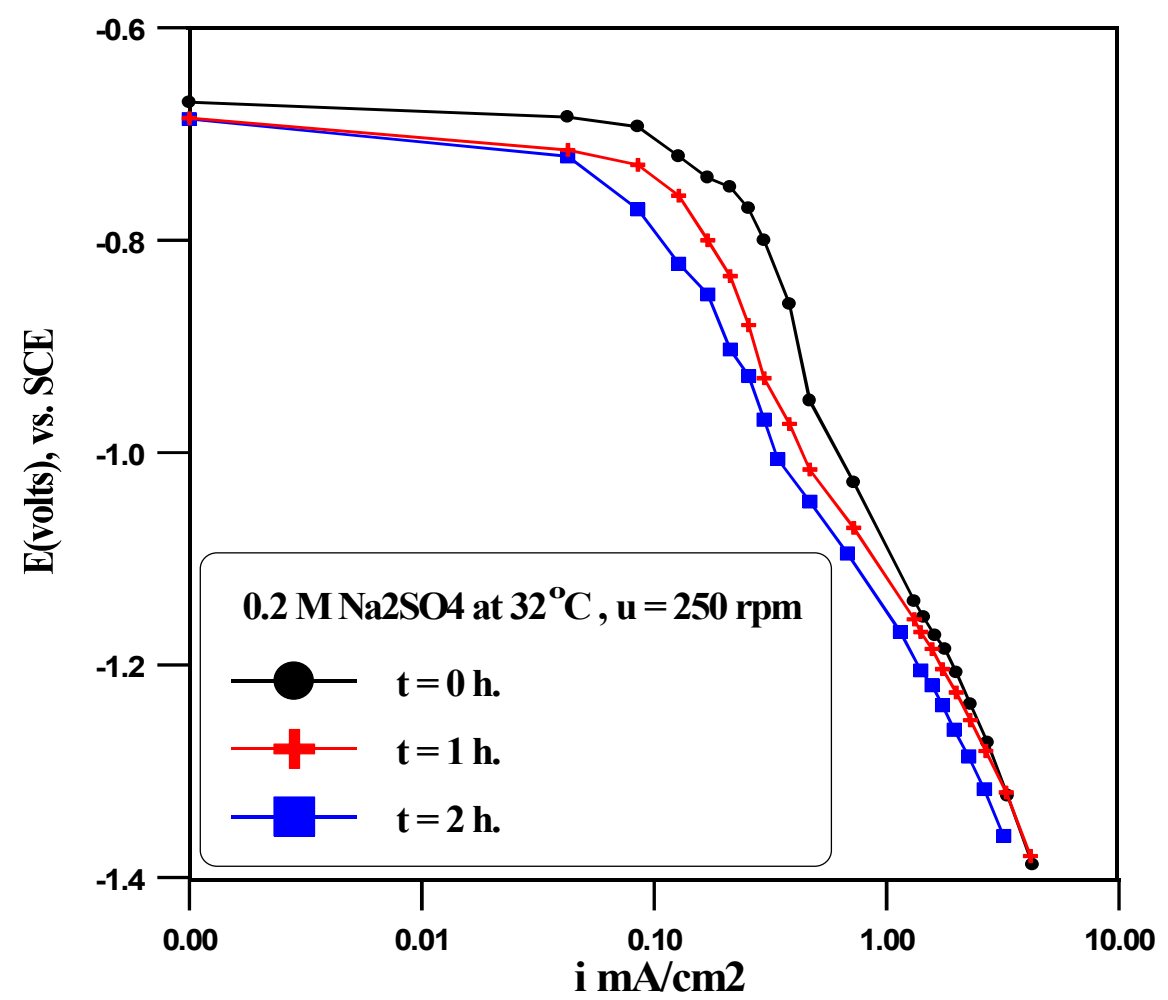

Fig. ( 10) Polarization curve at $\mathrm{u}=250 \mathrm{rpm}$ and $32{ }^{\circ} \mathrm{C}$ in $0.2 \mathrm{M} \mathrm{Na}_{2} \mathrm{SO}_{4}$ solution at different time intervals.

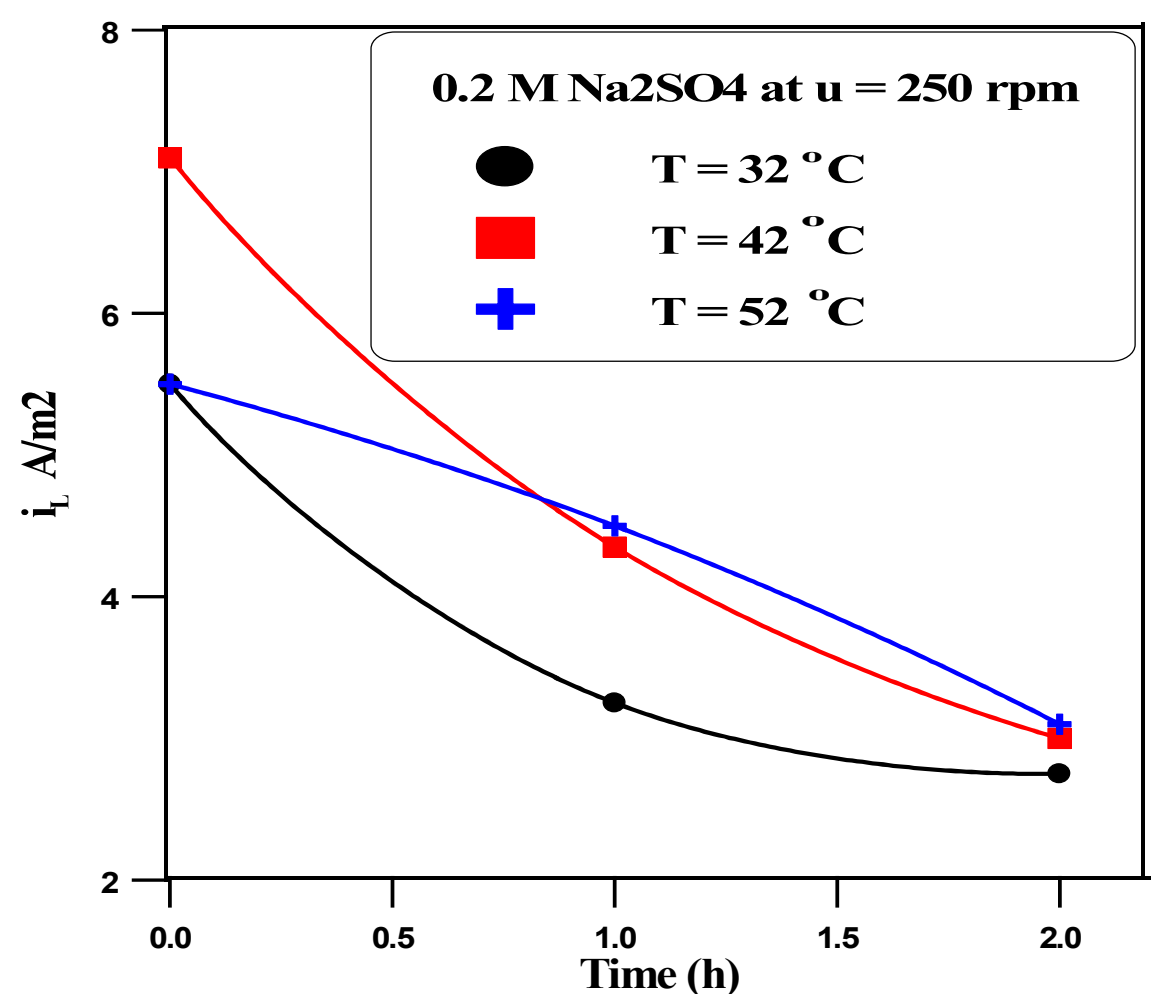

Fig. (11) Effect of time on the $i_{L}$ at the three temperatures with velocity $250 \mathrm{rpm}$ 


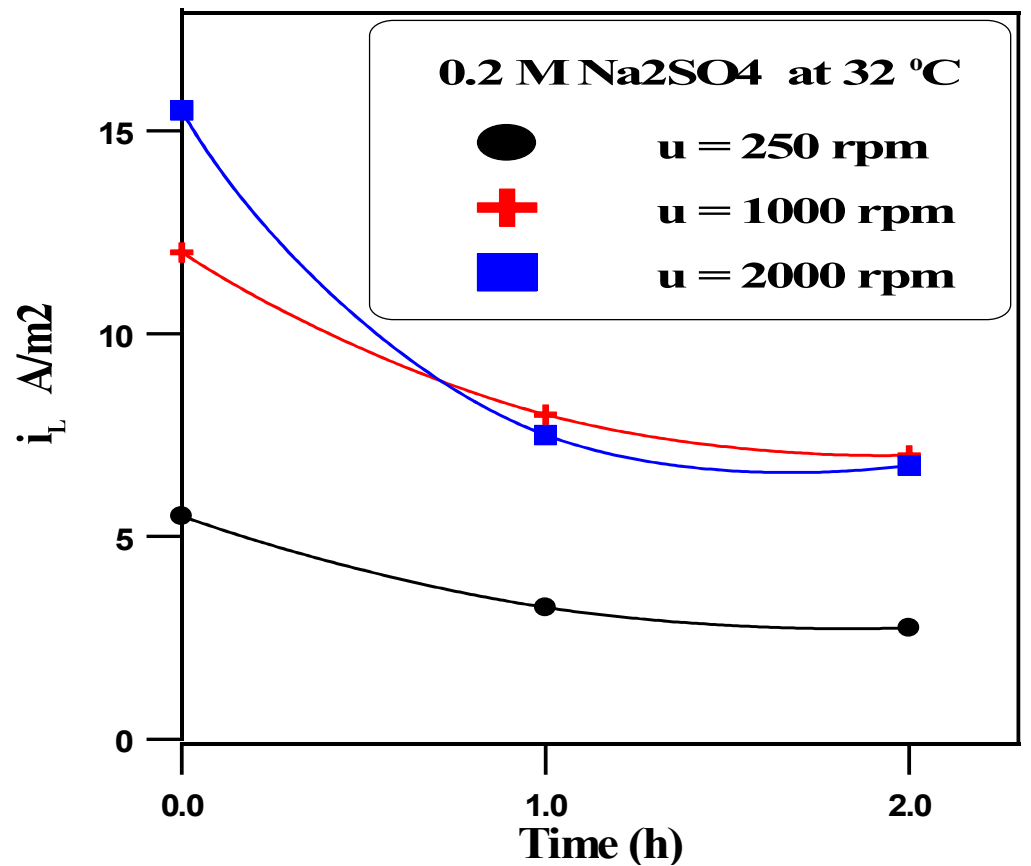

Fig. (12) Effect of time on $i_{L}$ at three velocities at $32{ }^{\circ} \mathrm{C}$.

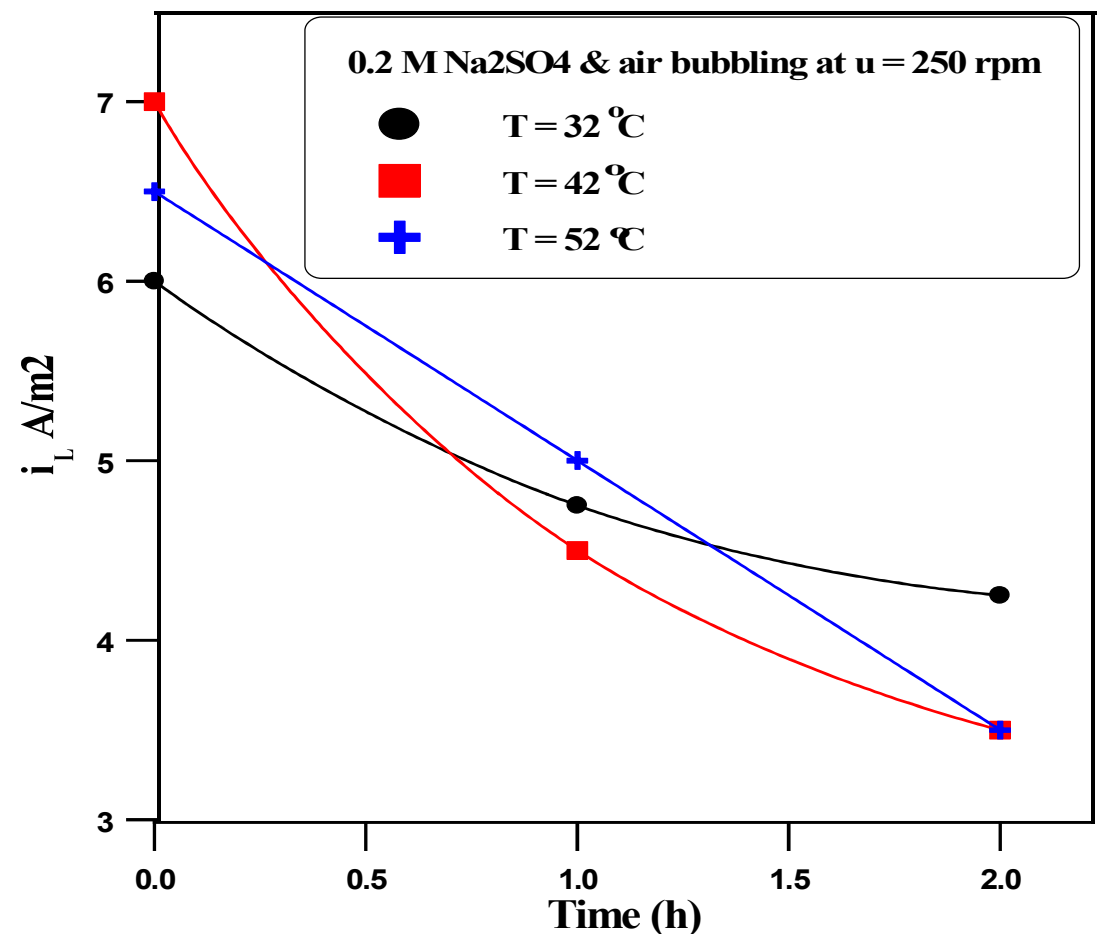

Fig. (13) Effect of time on $i_{L}$ at $250 \mathrm{rpm}$ and different tempreatures with air bubbling 


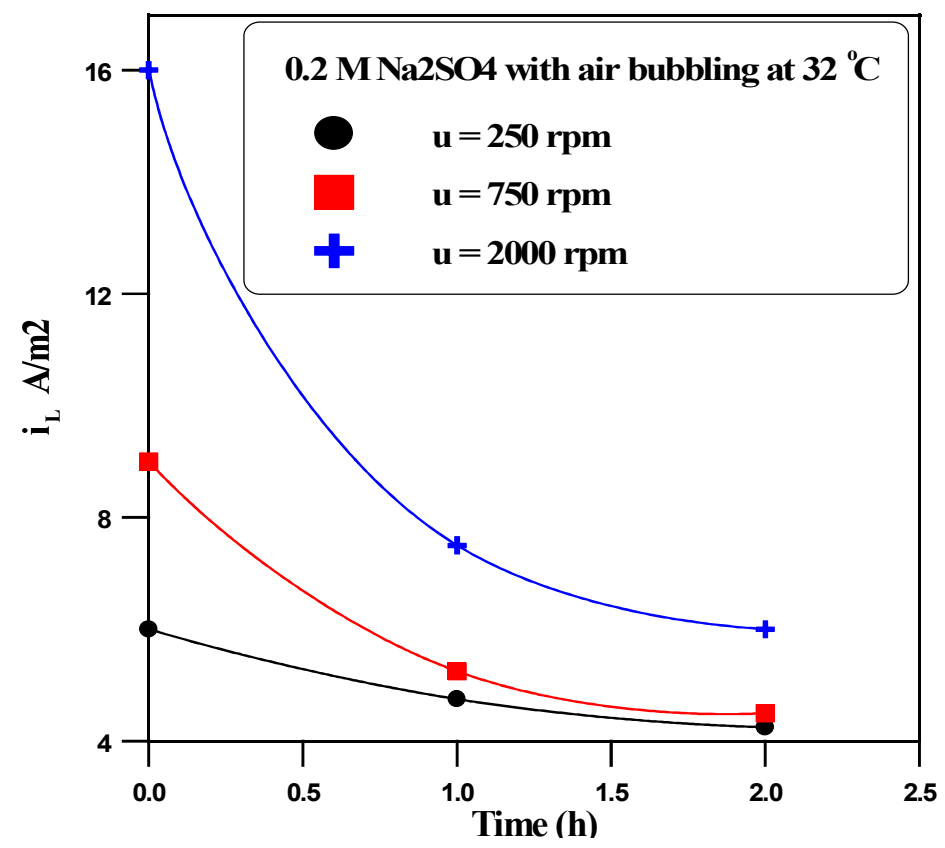

Fig. (14) Effect of time on $i_{\mathrm{L}}$ at $32^{\circ} \mathrm{C}$ and different velocities.

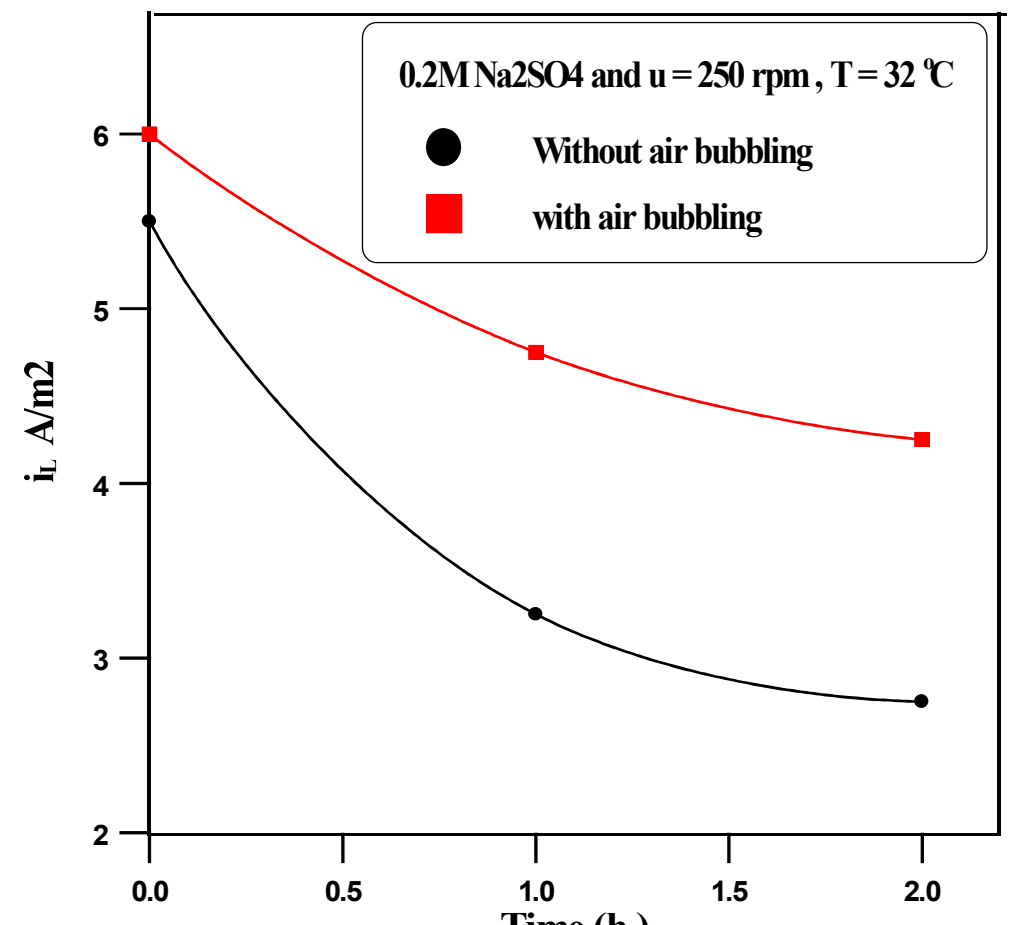

Fig. (15) $i_{L}$ vS. .time with and without using air bubbles at $32^{\circ} \mathrm{C}$ and $250 \mathrm{rpm}$. 


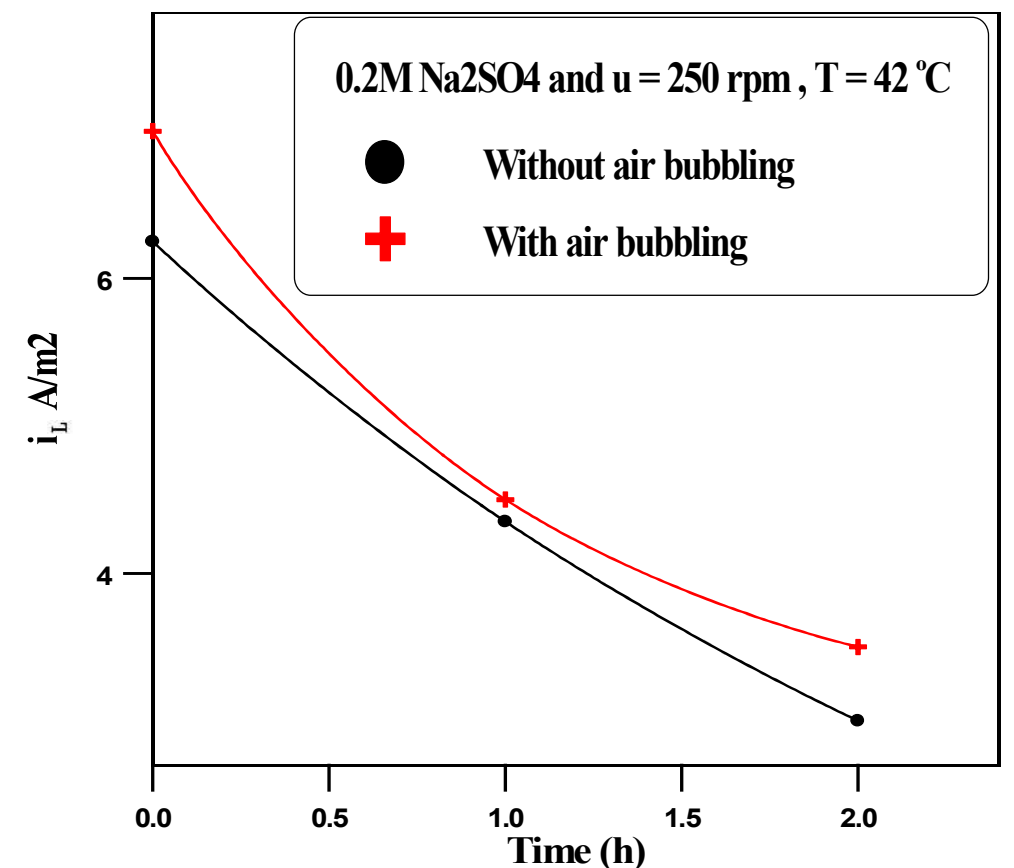

Fig. (16 ) Variation of $i_{L}$ vs. time with and without using air bubbles at $42^{\circ} \mathrm{C} \& 250 \mathrm{rpm}$



Fig. (17) $i_{L}$ vs. time with and without air bubbling at $52^{\circ} \mathrm{C}$ and $250 \mathrm{rpm}$ 


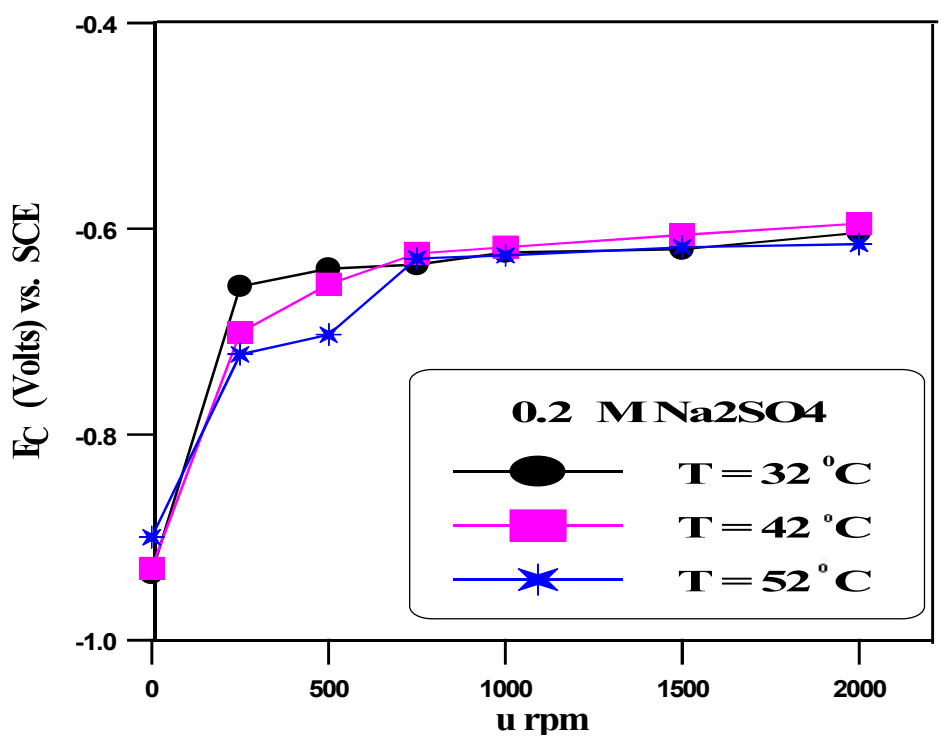

Fig. (18) Ec vs. velocity in $0.2 \mathrm{M} \mathrm{Na}_{2} \mathrm{SO}_{4}$ at different temperatures.

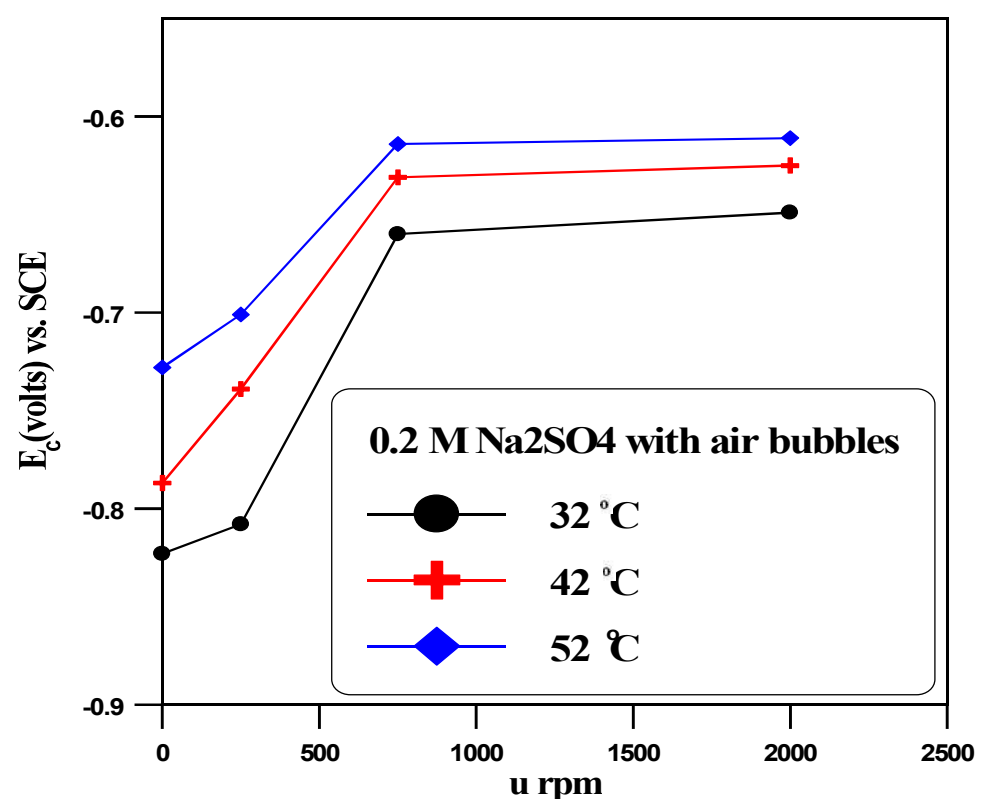

Fig. (19) $E_{c}$ vs. velocity at different temperatures with air bubbles. 